\title{
On Introducing "Ecological" Education into the Campus
}

\author{
Zhigang $\mathrm{Yu}^{*}$, Shufang Li, Yang Chen, Tianwei Yan \\ School of Civil Engineering \\ Chongqing Vocational Institute of Engineering \\ Chongqing 402260, China \\ *Corresponding Author
}

\author{
Jiaye $\mathrm{Wu}$ \\ Sichuan Central Inspection Technology Inc. \\ Chengdu 610045, China
}

\begin{abstract}
The advantage of construction and competition of higher vocational colleges lies in good ecological connotation, which is related to the vital interests of college students, social harmony and stability and sustainable economic development. In the visual field of "ecological" education, the paper puts forward some suggestions to strengthen ecological education, deepen ecological consciousness and realize the development of education "ecology": pay attention to the education of life ontology, cultivate students' interest in learning, create space for the development of original personality, and promote the education of innovation and entrepreneurship, and it should, under the guidance of new ideas of education, regard the "ecological" education of the students as the break-through point of enhancing the development of education.
\end{abstract}

Keywords-“ecological” education; “ecology” concept; life noumenon; Innovation and Entrepreneurship

\section{INTRODUCTION}

High-level vocational education should be recognized by the society, not only because of its high level of technical skills, but also because of its advanced and leading thought and spirit. Technical skills without thoughts and spirits cannot be respected by society [1]. Helvetius, the French philosopher, once said that "even ordinary children, as long as they are educated properly, will become an extraordinary person". Yu's father failed to control the floods by blocking them, but $\mathrm{Yu}$ succeeded by dredging it, which can inspire every teacher. We should aim at cultivating intact people, healthy people, and harmonious people, and give students a space to think, so that each student can obtain independent, full, and coordinated development and let education go to the door of "ecology". "Ecological" education is not only a kind of natural education, but also an inevitable choice to realize the sustainable development of education.

Change the concept of talent training, focusing on personalized and refined training. With the continuous deepening of the supply-side structural reforms, the era of socialized mass production has come. With the continuous upgrading and adjustment of industrial structure and the renewal and reform of production mode, the corresponding requirements for talent training in colleges and universities are

Chongqing Vocational Institute of Engineering "Top Ten Education" Quality Project, "Intelligent Civil Engineering"-Exploring the New Mode of Integration of Industry and Education under the Strategy of Transportation Power. Higher Vocational Education Double Base Construction Project of Chongqing Municipal Education Committee, Chongqing Vocational Institute of Engineering Construction Engineering Technology Specialty (Group) Double Base Construction Project. naturally put forward. Subsequently, colleges and universities should keep up with the national development trend and adjust the talent training concept in accordance with market orientation, which is related to the vital interests of college students, the harmonious stability of society and the sustainable development of economy [2]. From the perspective of "ecological" education, this paper puts forward that as the engineer of human soul, teachers should strengthen the "ecological" education, keep the awareness of "ecological" education at all times, take the new education concept of "student-oriented" as the guidance, and devote to promoting the sustainable development of "ecological" education from the following aspects.

\section{SeVeral AsPects ARE COMmitTed to Promoting THE "ECOLOGICAL" SUSTAINABLE DEVELOPMENT OF EDUCATION}

\section{A. Pay Attention to the Education of Life Ontology}

Complete education is the content selection of life ontology education. Education should not only choose contents related to the growth and development of human natural life, but also pay attention to the continuous enrichment and satisfaction of human value, life, emotion and wisdom, emphasizing the continuous enhancement of human consciousness [3]. Marx said that "knowledge is the only performance of consciousness", and "knowledge is the only objective action of consciousness". Consciousness is a dynamic response to objective reality. Every educational activity of human is not only the objective practice of consciousness, but also requires the active participation of human emotion and will. In the educational practice of life, people form, experience, test and sublimate their spiritual value, which is what we need to promote and advocate most in education. If the spiritual life is ignored in our education, it means that our education is a kind of incomplete education, and also indicates that our the existence of life is a kind of incomplete existence. The education of life ontology is a kind of education related to the whole life. In the reform and development of education in the new era, fostering virtue and cultivating people through education is the new response of current education to the question of cultivating what kind of people for a long time. It is the only way to train the builders and successors of the socialist cause and the return to the foundation of university education 
[4]. Teaching is not only a process of imparting knowledge, but also a process of cultivating students' correct values and beliefs.

\section{B. Cultivate Students' Interest in Learning}

Interest is a strong motivation for learning and a premise for voluntary learning. Einstein said that "interest is the best teacher". The famous educator Sukhomlinsky also once said that, "if teachers do not try their best to make students be in the state of emotional and intellectual stimulation, but eager to teaching knowledge, then such knowledge can only result in the indifferent attitude, and the passionless work will bring fatigue".

"Worrying ahead of the people, enjoying after the people" is Fan Zhongyan's responsibility for the rise and fall of the world. "A death befalls all men alike, my loyal heart will shinning in the pages of history" is Wen Tianxiang's noble and righteous spirit. "The River All Red" makes the spirit of Yue Fei famous through the ages. Teachers should combine the actual performance of students and exert their subjective initiative to gradually promote the original perceptual knowledge to rational knowledge and cultivate their interest in learning. Pay attention to the use of sweet, interesting and meaningful language, melodious intonation and beautiful vocabulary to motivate students to think actively, explore deeply and refine the beautiful factors from the teaching materials, make full use of these factors to cultivate students, make students feel knowledge from effective methods and flexible and ingenious skills, and through optimizing their own methods to sublimate students' knowledge, so as to achieve the teaching effect of "the rain sneaks into the night with the rain, moistening thing silently".

For example, the article of Battle of the Red Cliff was taught in primary schools, middle schools and universities and colleges. If when teaching in the class of primary school, teachers can guide students to analyze its profound meaning, so that they can understand that as long as they have sufficient preparation, appropriate strategy and the confidence to overcome difficulties then they can solve the difficulties to the maximum. As well as clarifying the personality characteristics of important people, such as Zhu Geliang's resourcefulness, Zhou Yu's narrow-mindedness, Cao Cao's suspicious nature and Huang Gai's gallantry, the main plots and the fact that the Battle of the Red Cliff is one of the three most famous battles in Chinese history, which will not only cultivate students' interest in learning, but also stimulate students' thirst for knowledge.

\section{Create a Space for the Development of Unique Personality}

Respect for individuality is respecting for creativity in essence, because innovation comes from the people with original spirit and unique thinking personality. Innovation is the soul of a nation's progress and the inexhaustible driving force for a country's prosperity. Education should spread the wings of innovation and create a space for innovation, because if students only enjoy the sunshine and warmth then they will always be the passive accepted objects. Nowadays, the education for all-round development especially emphasizes the cultivation of students' innovative consciousness, spirit and ability, so as to promote the sublimation of their ideological realm and the shaping of their sound personality, and to cultivate their noble moral sentiment. Teachers should create all the conditions for students to use their hands and brains, to listen and think, so that they can cultivate students' imagination and creativity. Consequently, to improve the students' cultural accomplishment and quality, develop their intelligence and improve their ability.

Thought determines outlet, quality determines grade, and orientation determines position. Innovation education advocates student-oriented education and is a new teaching concept that filled students with humanistic spirit and creative passion. In the new era, teachers should change their former teaching concepts, provide students with more broad space for development, perfectly cultivate their personality, respect and arouse students' subjective consciousness, advocate and give play to the students' initiative and creativity. After making clear the difference of each student, the teacher should know them fairly well and treat them differently. At a seminar for middle school teachers in Beijing, Professor Yang Zhenning suggested that "teachers should pay more attention to the differences of the students". We should create a vivid, lively, equal and free education atmosphere, so that students can give full play to their initiative and actively participate in learning. Mobilize all positive factors to cultivate students' cognitive ability, association ability and innovative thinking in a subtle way. Innovation must rely on imagination, and only with rich imagination can students' innovation ability be well developed. Therefore, in the teaching, we should pay attention to the full use of various teaching means, relate to the actual situation, and carry on the training of daring to imagine, innovate and break the routine.

\section{Promote the Education of Innovation and Entrepreneurship}

The Ministry of Education's “Opinions on Vigorously Promoting Innovation and Entrepreneurship Education in Colleges and Universities and the Independent Entrepreneurship Work of College Students" clearly emphasizes that actively carrying out innovation and entrepreneurship education in colleges and universities is a major strategic measure to serve the national innovative construction, an important way to cultivate students' innovative spirit and practical ability, and an important measure to promote the full employment of college graduates. In the development of higher education, we should deeply study and practice the scientific concept of development, deepen the reform of higher education, promote the development of students' innovation ability through innovation and entrepreneurship education, so as to provide intellectual support and expand employment for the country. In the series of strategic measures to build an innovative country, country, the innovation and entrepreneurship education in Chinese colleges and universities, as an important part, should be implemented in all aspects of college construction [5]. The theory of ecological education should be interpreted from two perspectives, namely, the macro perspective and the micro perspective [6]. In fact, the process in which college students receive innovation and entrepreneurship education is also the 
process in which the entire education ecosystem plays a role [7].

Innovation begins with problems. Mr. Tao Xingzhi, a famous educationist, once said, there are thousands and millions of discovery, but the starting point is to ask. The cultivation of students' innovative ability is inseparable from problems. Only problems can stimulate students' thirst for knowledge and make them devote themselves to learning activities. Einstein once said that asking a question is often more important than solving a question. Students should be encouraged to have a bold spirit of questioning the scientific theories and traditional views of their predecessors. As for questions about things that have not been revealed by the predecessors, some unique opinions in the debate, and novel thought and original ideas when considering problems, even if there is only a little novelty, we should fully affirm it. As for the reasonable and valuable side, teachers should also guide students to think further and expand the glittery factors in thinking. The exploring spirit of students often comes from questioning some common life phenomena and ideas, and the process of exploration is also the innovation process of thinking. Teachers should follow the cognitive rules in the teaching, according to the teaching needs, combined with the key points and difficulties of teaching and the blind spots of students' cognition, cleverly set up difficult questions, create problem situations, stimulate students' curiosity, and fully arouse students' enthusiasm for learning. Make students always in a state of active thinking, so as to achieve the purpose of mastering knowledge and cultivating innovation and entrepreneurship ability. Colleges and universities are an important training base for innovation and entrepreneurship education. The essence of innovation and entrepreneurship education is to cultivate people or talents with pioneering personality and divergent thinking, and cultivating cultural environment of innovation and entrepreneurship education is the most basic task.

To cultivate the cultural environment of innovation and entrepreneurship education, from the perspective of ecological sustainability, only by vigorously cultivating the culture of innovation and entrepreneurship education can we stimulate the endogenous power of university innovation and entrepreneurship education, and transform university innovation and entrepreneurship education from "policydriven" to "culture-driven" and from "power promotion" to "self-development" [8]. We can start from the following three aspects: Firstly, strengthen the education of innovation and entrepreneurship courses. When students are in colleges, we should mobilize all positive factors, vigorously promote innovation advantages and strengths of entrepreneurial activities, and focus on cultivating and improving students' innovation awareness and entrepreneurial skills. Teachers' practical experience often determines the ability of colleges and universities to cultivate innovative and entrepreneurial talents. Therefore, in order to improve the innovation and entrepreneurial ability of college students, it is necessary to carry out systematic reform of the teaching staff and enrich the practical experience of teachers. Secondly, the educational concept of "mass entrepreneurship and innovation" should be run through the whole process of high-quality talent training to create an ecological education atmosphere for co-construction and sharing within and outside the university. Teachers and students in colleges and universities have rich scientific and technological knowledge, continuous innovation vitality, and some their achievements have great market potential, but they lack the venue and practical experience to use their talents. The first-class hardware facilities and scientific research equipment in colleges and universities can provide support for College Students' Innovation and High-tech Business Incubator. College Students' Innovation and High-tech Business Incubator can provide accounting agency, bank account opening, industry and commerce, tax registration and other services for enterprises. Enterprises that are successfully incubated from the College Students' Innovation and High-tech Business Incubator should keep pace with the times, adopt advanced management systems, and promote the adopted systems, so as to adapt to the development of enterprises. Thirdly, education authorities can provide convenient green channels for college students to innovate and start businesses. The government can also provide college students a series of preferential policies in business registration, financial support, tax reduction and interest free, simplify various approval procedures, establish innovation achievements transformation platform, realize the patentability and convenience of scientific research achievements projects, and stimulate the entrepreneurial enthusiasm of college students.

\section{CONCLUSION}

To realize the "ecological" development of education, we should pay attention to the education of life ontology, cultivate students' interest in learning, create space for the development of original personality, and promote the education of innovation and entrepreneurship. Only when the concept of "ecology" is rooted in the heart of teachers, will they examine and treat everything of students with the ecological views, attitudes and methods, can they face and solve all kinds of problems calmly, and can they deal with everything in a very "ecological" way, so that the young generation can grow up freely, healthily and happily, and become themselves freely, healthily and happily.

\section{ACKNOWLEDGMENT}

Chongqing vocational institute of engineering "Top Ten Education" quality project, "Intelligent Civil Engineering"exploring the new mode of integration of industry and education under the strategy of transportation power. Higher vocational education double base construction project of chongqing municipal education committee: chongqing vocational institute of engineering construction engineering technology specialty (group) double base construction project.

\section{REFERENCES}

[1] B.J.Ding, Analysis on Culture Ecology of High Level Vocational Education, Issue No. 6. Chinese Vocational and Technical Education, 2020, pp.60-64.(In Chinese). 
[2] Y. CUI,Construction of Employment Innovation Path for College Graduates Based on Supply-side Vision, Issue No. 6. On Economic Problems,2020, pp.80-87. (In Chinese).

[3] Y.P. Li, Education under the View of Life Noumenon, Issue No. 3. Educational Research, 2006, pp.37-40. (In Chinese).

[4] M.C.ZHANG, Y.Y. DONG, The Ecological Construction of Normal Education Reform and Development in Universities,Issue No. 3, vol. 12. Contemporary Education and Culture ,2020, pp.69-74. (In Chinese).

[5] D.M.GUO, H.X. WANG, Deepening the reform of innovation and entrepreneurship education in colleges and universities, Issue No. 8. China Adult Education, 2018, pp.57-58. (In Chinese).
[6] J.H.SUN, Cultivation of creative thinking from the perspective of ecosystem theory, Issue No. 12. Modern Education Science, 2014,PP.11-12. (In Chinese).

[7] Y.DONG, Y. XU,The construction of ecological development system of entrepreneurial education in colleges and universities, Issue No. 2. China University Students Career Guide, 2013, PP.42-46. (In Chinese).

[8] C.X. CHEN,Analysis on the Main Problems and Ecological Construction of Innovation and Entrepreneurship, Issue No. 3, Vol. 45 Education in Universities of China Journal of Wuling, 2020, pp.134-140. (In Chinese). 